\title{
Impact of Engineering Insurances on the Growth of Turkish Construction Sector
}

\author{
Suna Ozyuksel ${ }^{1} \&$ Yavuz Bacak ${ }^{2}$ \\ ${ }^{1}$ Finance Institute, Head of Insurance and Risk Management Department, Istanbul Commerce University, Istanbul, \\ Turkey \\ ${ }^{2}$ Finance Institute, Insurance and Risk Management Department, PhD Student, Istanbul Commerce University, \\ Istanbul, Turkey \\ Correspondence: Yavuz Bacak, Finance Institute, Insurance and Risk Management Department, PhD Student, \\ Istanbul Commerce University, Imrahor Cad. No:88/2 Beyoglu, 34445 Istanbul, Turkey. Tel: 90-532-343-8989. \\ E-mail: yavuzbacak@gmail.com
}

Received: May 10, 2020

Accepted: May 27, 2020

Online Published: June 28, 2020

doi:10.5539/ijef.v12n8p28

URL: https://doi.org/10.5539/ijef.v12n8p28

\begin{abstract}
Engineering insurances are significant risk transfer instruments in terms of construction risk management. The construction sector comprises approximately $8 \%-9 \%$ of the GDP of Turkey and employs 2 million people according to 2019 data. It plays a vital role in the economic development of Turkey. When the direct and indirect effects of the construction sector are taken into account, its share in the economy of Turkey reaches around $30 \%$. Construction projects are investments that bear various risks and need meticulous execution. For this reason, it is thought that proper management of the associated risks in the construction sector by means of the risk transfer to insurance sector via engineering insurances will contribute the sustainable growth of the construction sector. In this context, the effect of engineering insurances on the growth of the construction sector is examined empirically, and positive results have been reached. The increase in the use of engineering insurance constitutes a reason for growth of the construction sector. Results of the Granger Causality test, conducted for analysis of causality, indicate that there is causality. Additionally, a mathematical model is investigated in order to observe the effect of the engineering insurances growth, on the growth of the construction sector by utilizing the simple linear regression method. In the study, the model is found to be statistically significant. As a result of the model, it is shown that the growth of engineering insurance has an impact on the growth of the construction industry.
\end{abstract}

Keywords: construction insurance, construction sector growth, construction risk management, engineering insurance, relation between engineering insurance and construction sector growth

\section{Introduction}

The construction sector is one of the cornerstones of the economy. It keeps the economy dynamic and sustainable together with the subsectors related to it. The advancement of civilization cannot be envisaged without construction projects and construction investments. The construction sector in Turkey is rapidly developing. The preferences of the governments in power, the numerosity of the subsectors that serve to the construction sector as well as the socio-economic needs are perceived as the triggering factors of this development. The number of Turkish firms that take part in significant projects is increased, and some observable technological advancements that facilitate competitiveness occurred. A framework defined by an increase in the number of firms, investments in technology, increasing competitiveness etc. indicates a trend of a profit squeeze. In this vein, unforeseeable and not adequately analyzed risks also pose a severe danger for the sector. The construction projects are complicated investments with numerous risks. Insurances, especially engineering insurances with respect to construction projects, are crucial risk transfer instruments. Engineering insurances, as one of the construction risk transfer tools, are regarded as having an essential role in construction risk management. Engineering insurances are considered to be related to the construction sector risk management and consequently, to the growth of the construction sector. The effect of the utilization of engineering insurances as a tool for risk management on the growth of the construction sector is open to research and needs to be analyzed. Our study analyzes the impact of engineering insurances on the growth of the construction sector and aims to arrive at some findings and conclusions. The results revealed with the help of 
statistical methods would aid the inquiry of the topic.

\section{Construction Sector in Turkey}

Turkish Language Institution defines construction as "civil work, building" (Turkish Language Institution, [TDK], 2020). Construction composes of works on buildings, roads, railways, highways, airports, docks, harbors, shipyards, bridges, tunnels, subways, viaducts, sports facilities, infrastructure, pipelines, communication and energy transmission lines, dams, power plants, refineries, irrigation facilities, soil reclamation, flood-prevention and stripping; and installation, manufacture, preparation of site materials, transportation, completion, large scale-repair, restoration, landscaping, drilling, demolition, reinforcing and assembly related with the endeavors stated above and similar construction endeavors (Public Procurement Law, [KIK], 2002). Since the early ages, construction works made for accommodation, urbanization, infrastructure, transportation, the struggle against nature, and power generation have been providing the continuation and expansion of the societies. All individuals are interested in estate ownership or construction work at some fragment of their life (https://www.insaatsantiye.com/insaat-nedir). Engineering moved more and more towards science, and its basic understanding and definition have become obscure. Civil engineering, which was described in the 1828 charter of the Institution of Civil Engineers as "the art of directing the great sources of power in nature for the use and convenience of man" has indulged in the science of analysis (Bunni, 2003). The construction sector is a significant part of the economy due to its intensive utilization of labor, contribution to the socio-economic welfare, and its direct links with the production processes of hundreds of different types of goods and services. Moreover, the value-added and employment it generates locates it as the engine of the national economies. Turkey's construction sector, which is predicated on mostly domestic capital, concerns hundreds of different occupations and positively effects employment and production processes. The sector, which possesses a vast experience and potential on both national and international level, is called as a locomotive sector as a consequence of its ability to stimulate more than 200 subsectors linked to it (Koç, Kaya, \& Şenel, 2017). Construction is also regarded as a branch of the service sector, which comprises of every underground and aboveground structure that is beneficial to the society (Karluk, 2002). Since long ago, the construction sector is accepted as an important constituent of economic development. The reason for this is the construction sector's substantial links to the other sectors in the economy (Gündeş, 2011). When focused on the effective demand the sector has created, it is observable that the construction sector triggers the economic growth by purchasing vast amounts of raw material and intermediate goods from other sectors, thus creating vitalization for those sectors. In theory, the wave of vitalization created by a sector that purchases intermediate goods would also spread to the sectors from which intermediate-good suppliers themselves purchase goods and services. As a result of this, it can be stated that sectors that purchase a lot of intermediate goods and services, such as the construction sector, would provoke economic growth via the multiplier effect. When it is investigated with a focal point of supply, the construction sector plays a crucial role by providing all of the necessary construction and infrastructure that other sectors need for their production (Gündeş, 2017). The construction sector, which corresponds to nearly $8 \%$ - 9\% of Turkey's GDP and employs 2 million people, is a major factor for the economic development of Turkey. When the direct and indirect effects of the construction sector are taken into account, its share in the economy reaches a level of 30\%. According to the "Top 250 Global Contractors" report published in August 2019, Turkey claims second place with 44 firms after China. Turkey has been preserving its place on this list for the last ten years (Turkish Contractors Association, [TMB], 2020).

The development of the construction sector in Turkey and its share in the GDP is demonstrated in Figures 1 and 2 based on TurkStat data. TurkStat data include the data of GDP by Production Approach in Chain Linked Volume Index. TurkStat datas are gathered from the gross domestic product in chain linked volume, index and percentage change, by kind of economic activity, Quarter IV: October-December, 2019 Table. Tables comprise data for the period between 2007 and 2019. Figure 1 shows the total economic activity of the construction sector and the total value of all sectors (GDP before taxes and subsidies are accounted for) by year. Figure 2 expresses the same data in percentage terms over years. In Figure 1 and 2, GDP of construction sector is referred as INSGSYIH and total value of sectors (GDP before taxes and subsidies are accounted for) is referred as GSYIH. The share of the construction sector in GDP and its significance is observable in Figures 1 and 2. 


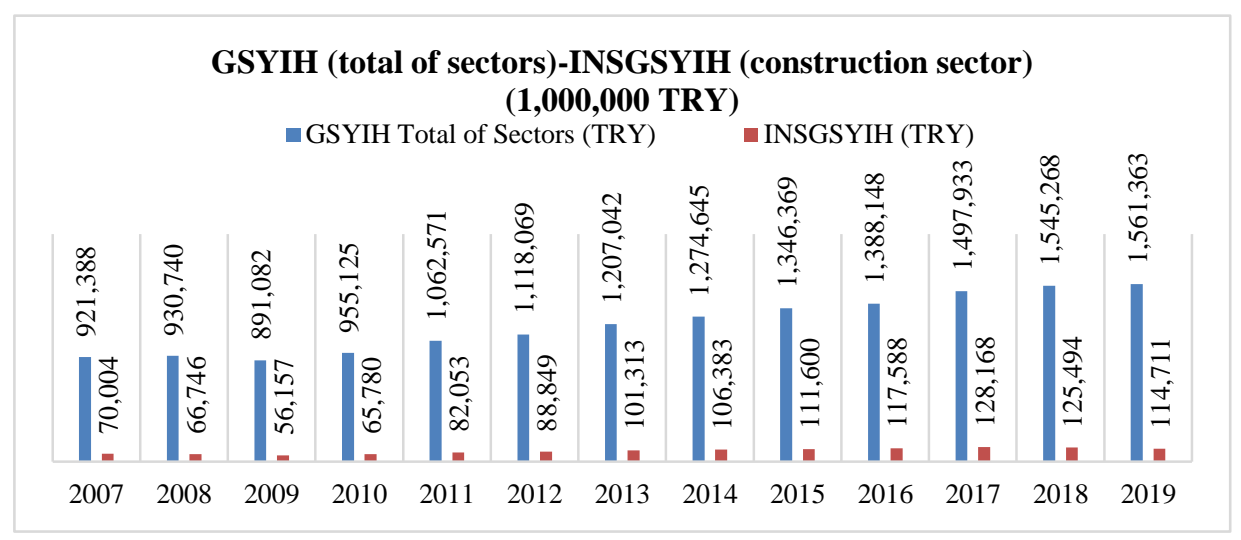

Figure 1. Gross domestic product of Turkey and construction sector $(1,000,000$ TRY)

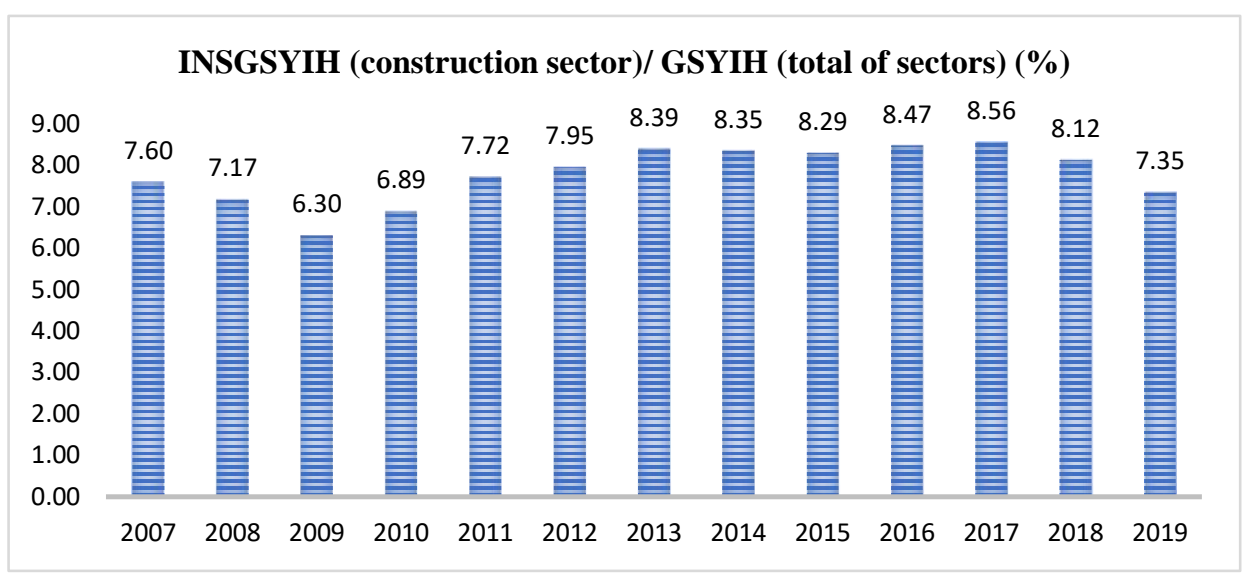

Figure 2. The share of the construction sector in gross domestic product of Turkey as percentage

Figure 3 compares the growth rate of the overall economic activity and the business activity of the construction sector between 2008 and 2019 by utilizing the same dataset. As can be seen in the figure, the construction sector exhibits high growth rates between 2010 and 2017. The growth acceleration of the construction sector is higher than or equal to the acceleration of the overall economic growth.

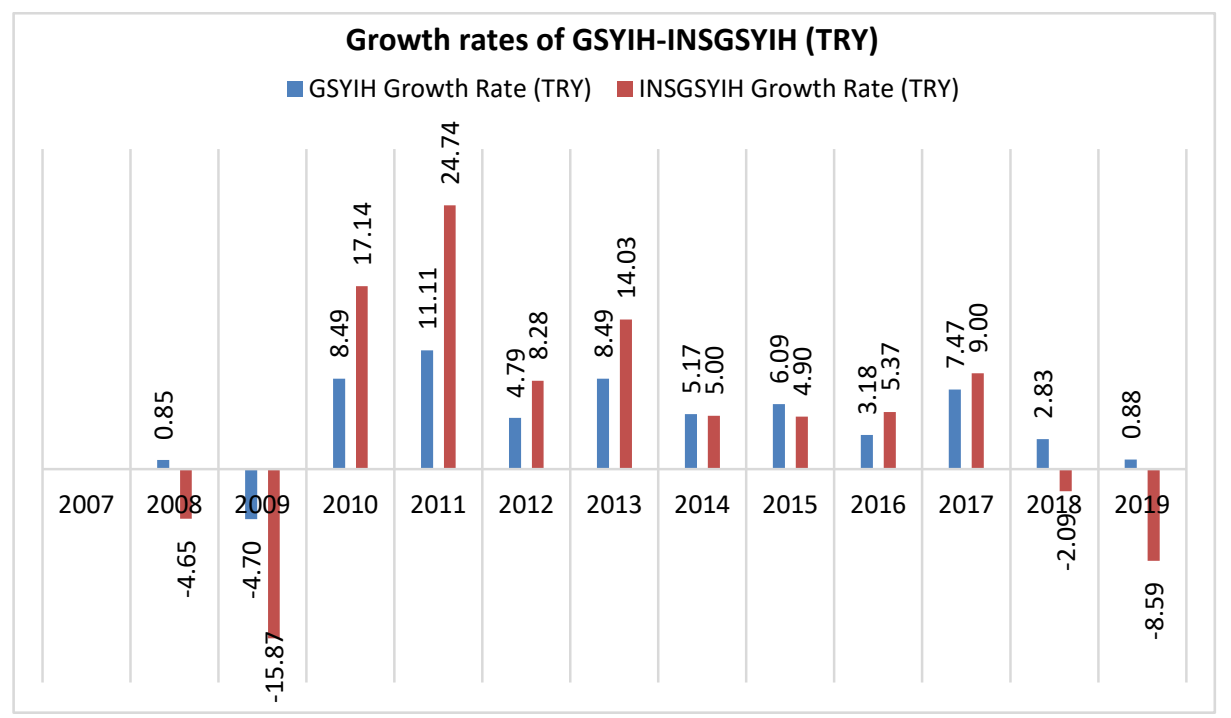

Figure 3. The growth rates of the gross domestic product of Turkey and construction sector as percentage 


\section{Engineering Insurances in Turkey}

Engineering Insurance is a type of insurance that emerged in the mid-19 $9^{\text {th }}$ century, during the Industrial Revolution (Manson, 2000). Engineering insurances, provided as part of insurance activities started to gain ground in Turkey during the second half of the 1960s. The insurance branch which used to be provided under the name of Machinery-Erection Insurances has been branded as Engineering Insurances as per the Communique published by the Undersecretariat of Treasury since January 1st, 2006 (Özbolat, 2009). Engineering insurances in Turkey are provided under four main categories. Machinery breakdown insurance, erection all risk insurance, construction all risk insurance, and electronic equipment insurance are the constituents of the engineering insurance branch (https://www.tsb.org.tr/sigorta-branslari.aspx?pageID=622). Machinery breakdown insurance provides coverage for damages on machinery, which has been produced or assembled and completed the trial period; that occur during its operation or due to an unexpected factor that happens during maintenance, cleaning, revision, or relocation of the machinery. In return for an additional premium, additional coverage may be purchased for strike, lock-out, disturbance, riots, activities of terrorism and sabotage, express transportation, overtime, vacation pay, wage increase, foundations and mounts of the machinery, additional comprehensive insurance coverage (hit, crash, rollover, landslide, fire, lightning, earthquake, and flood may be included in the coverage) for mobile machinery (especially for construction machineries) (www.tsb.org.tr/makine-kirilmasi). Erection all risk insurances are the ones that offer compensation for damage or loss that may occur during erection or installing of factories, industrial areas, mechanical or electrical parts, and facilities. The sum insured equals the contract value and composes of the costs for units to be erected, transportation, freight, insurance, customs duties if applicable, duties, fees, labor, assembly and commissioning (www.tsb.org.tr/makine-montaj-sigortalari). Construction all risk insurances are insurance contracts that provide coverage for any loss or damage on goods and property that occurs during the construction of roads, dams, bridges, hospitals, residential buildings, etc. The construction may refer to the entire project or may be limited to some extensions to an existing property. The damages in the construction field should be caused by an unforeseeable and sudden event that has not been excluded from coverage, in order be eligible for insurance coverage. The term of the coverage starts with the beginning of the project and ends with the temporary acceptance of the constructed building to the principal. If requested, coverage can be extended to include risks such as debris removal, third party liability, cover of extra charges for airfreight, inland transit, maintenance period, strike, lock-out, terrorist attack, earthquake, etc. in return for extra premium (www.tsb.org.tr/insaat). Electronic equipment is the kind of insurance that provides compensation for monetary loss that emanates from sudden and unexpected events that occur whilst electronic machinery, device, information technology systems which are working properly or during on-site cleaning, maintenance or relocation of them as well as earthquakes. Besides these events, many circumstances such as client error or neglect, completed or attempted theft, faulty design, voltage fluctuation, firefighting, demolition, and rescue that may cause damage can be included in the coverage (www.tsb.org.tr/elektronik-cihaz). Engineering insurance is a specialty line of business that provides protection against losses from unforeseen circumstances during the construction and operation of plants, buildings, and infrastructure. With annual premiums of around USD 21 billion, it represents only a small part (around 3\%) of the overall commercial insurance market. However, without such cover, many construction projects and the operation of vital machinery would prove prohibitively risky to undertake (Swiss Re, 2018). Premium generation of the insurance sector excluding life insurances in Turkey realized as 57.882 billion TRY in 2019. The engineering insurances encompass 2.302 billion TRY in this pool of premiums. This corresponds to approximately $4.0 \%$ of the total premium that is generated (www.tsb.org.tr/resmi-istatistikler). Premium information regarding engineering insurances is recorded since Q4 of 2006 by the Insurance Association of Turkey. Figures 4 and 5 display the progress of the engineering insurances in Turkey in USD and TRY. Data is gathered from the Insurance Association of Turkey. Development of engineering insurance premiums shows an increasing trend on the chart prepared in TRY over the long term. Upon close inspection, a fluctuation is observable on the chart prepared in USD especially after 2013 because of the depreciation of the Turkish Lira against US Dollar. In Figure 4 and 5, total engineering insurance premium is referred as MUHPRIM. 


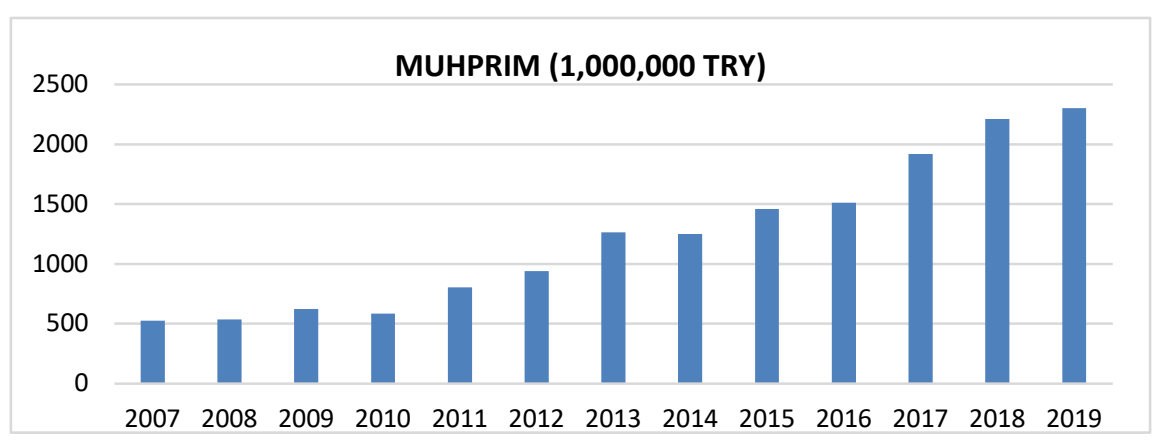

Figure 4. Progress of engineering insurances in Turkey (TRY)

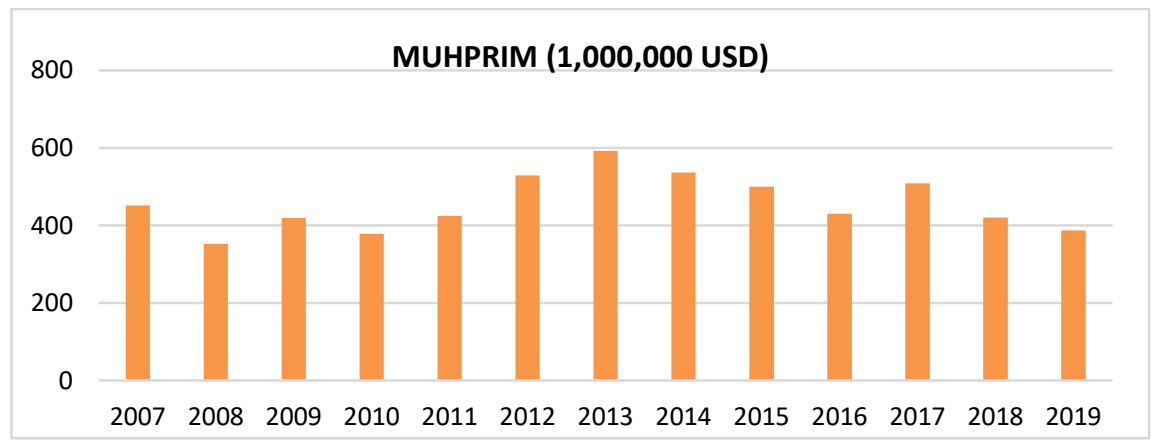

Figure 5. Progress of engineering insurances in Turkey (USD)

\section{Investigation of the Relationship between Engineering Insurances Growth and Construction Sector Growth}

The importance of the insurance-growth nexus is growing due to the increasing share of the insurance sector in the aggregate financial sector in almost every emerging and mature market economy (Haiss \& Sümegi, 2008). Insurance companies, together with mutual and pension funds, are one of the biggest institutional investors in stock, bond and real estate markets. The growing investment activities also emphasize the possible importance of insurance companies as an institutional investor in economic growth (Catalan et al., 2000; Rule 2001). The risk transfer function of insurance, which is one of the essential roles of the insurance sector, contributes to economic growth. Insurance serves to endurance of the economic cycle by decreasing uncertainty and volatility. Through this process, the risk that the economy bears is reduced, high volume expenditures that result from the encounter of individuals and firms with risk is avoided, disbursements are minimized and thus, economic activity escalates. (Haiss \& Sümegi, 2008).

In Turkey, the momentum of the engineering insurances has been in an upward trend since 2007, the year it started being recorded. Figure 4 shows this momentum as the size of total engineering insurance premiums. When the growth of the construction sector is investigated, Figure 1 shows a steady increase in the total revenue of the construction sector of Turkey between 2009 and 2017. At this juncture, the parallelism between the development of the engineering insurances and the growth of the construction sector is noticeable. When the graphs are elaborately reviewed, one can discern the positive growth in both engineering insurances and the construction sector as well as the parallelism between these growth figures.

\section{Statistical Analysis of the Relationship between Engineering Insurance and Construction Sector Growth}

When the relationship between the insurance sector and economic growth is questioned, it is observed that there are empirical studies generally conducted utilizing time series for different insurance products. With the help of scrutiny of the methodologies and econometric methods of these researches, the study has been conducted about the relationship between the engineering insurances and the growth of the construction sector. The relationship between the engineering insurances growth and the construction sector growth is analyzed by the use of empirical data. Our variables contain 53 data between 2007 Q4 and 2019 Q4. Data is gathered from TurkStat and the Insurance Association of Turkey. The data gathered is analyzed with the help of econometric analysis software EViews 8. Table 1 presents the data set used in the study. 
Table 1. Variables used in the study

\begin{tabular}{|c|c|c|c|c|}
\hline \# & Quarter & $\begin{array}{l}\text { Total Engineering Insurance Premiums } \\
\text { (MUHPRIM) }\end{array}$ & $\begin{array}{l}\text { GDP of Construction Sector } \\
\text { (INGSYIH) }\end{array}$ & $\begin{array}{l}\text { Consumer Price Index } \\
\text { (TUFE) }\end{array}$ \\
\hline 1 & 2006Q4 & $135,219,974$ & $18,052,288,369$ & 134.49 \\
\hline 2 & 2007Q1 & $115,613,061$ & $13,496,716,757$ & 137.67 \\
\hline 3 & 2007Q2 & $145,132,366$ & $19,279,121,638$ & 139.69 \\
\hline 4 & 2007Q3 & $123,565,266$ & $18,167,356,294$ & 140.13 \\
\hline 5 & 2007Q4 & $139,045,789$ & $19,060,905,001$ & 145.77 \\
\hline 6 & 2008Q1 & $115,989,645$ & $13,722,966,927$ & 150.27 \\
\hline 7 & 2008Q2 & $198,179,241$ & $19,133,611,234$ & 154.51 \\
\hline 8 & 2008Q3 & $81,126,848$ & $17,118,025,616$ & 155.72 \\
\hline 9 & 2008Q4 & $140,853,339$ & $16,771,817,448$ & 160.44 \\
\hline 10 & 2009Q1 & $154,141,259$ & $11,033,964,807$ & 162.12 \\
\hline 11 & 2009Q2 & $160,554,839$ & $15,243,995,806$ & 163.37 \\
\hline 12 & 2009Q3 & $145,048,562$ & $14,319,400,016$ & 163.93 \\
\hline 13 & 2009Q4 & $164,146,289$ & $15,559,608,304$ & 170.91 \\
\hline 14 & 2010Q1 & $151,348,886$ & $11,985,909,979$ & 177.62 \\
\hline 15 & 2010Q2 & $146,571,134$ & $16,653,304,351$ & 177.04 \\
\hline 16 & 2010Q3 & $126,115,585$ & $18,944,563,624$ & 179.07 \\
\hline 17 & 2010Q4 & $158,501,066$ & $18,196,255,536$ & 181.85 \\
\hline 18 & 2011Q1 & $189,375,344$ & $15,269,937,340$ & 184.70 \\
\hline 19 & 2011Q2 & $191,215,536$ & $20,726,473,590$ & 188.08 \\
\hline 20 & 2011Q3 & $174,415,063$ & $22,974,777,119$ & 190.09 \\
\hline 21 & 2011Q4 & $247,593,973$ & $23,082,227,742$ & 200.85 \\
\hline 22 & 2012Q1 & $219,856,325$ & $16,808,035,093$ & 203.96 \\
\hline 23 & 2012Q2 & $259,792,174$ & $22,329,092,291$ & 204.76 \\
\hline 24 & 2012Q3 & $189,142,201$ & $24,725,470,745$ & 207.55 \\
\hline 25 & 2012Q4 & $272,523,223$ & $24,986,006,918$ & 213.23 \\
\hline 26 & 2013Q1 & $412,124,418$ & $20,096,951,100$ & 218.83 \\
\hline 27 & 2013Q2 & $271,530,549$ & $25,436,311,080$ & 221.75 \\
\hline 28 & 2013Q3 & $237,513,686$ & $28,244,963,695$ & 223.91 \\
\hline 29 & 2013Q4 & $340,943,284$ & $27,534,727,526$ & 229.01 \\
\hline 30 & 2014Q1 & $328,846,161$ & $23,913,755,940$ & 237.18 \\
\hline 31 & 2014Q2 & $332,300,371$ & $25,377,461,906$ & 242.07 \\
\hline 32 & 2014Q3 & $259,246,811$ & $28,542,197,139$ & 243.74 \\
\hline 33 & 2014Q4 & $328,165,132$ & $28,549,483,030$ & 247.72 \\
\hline 34 & 2015Q1 & $301,299,499$ & $23,399,565,632$ & 255.23 \\
\hline 35 & 2015Q2 & $416,664,087$ & $27,739,901,994$ & 259.51 \\
\hline 36 & 2015Q3 & $347,337,576$ & $29,598,649,817$ & 263.11 \\
\hline 37 & 2015Q4 & $394,777,954$ & $30,862,100,803$ & 269.54 \\
\hline 38 & 2016Q1 & $335,162,030$ & $23,981,986,365$ & 274.27 \\
\hline 39 & 2016Q2 & $387,310,066$ & $31,303,566,088$ & 279.33 \\
\hline 40 & 2016Q3 & $324,135,479$ & $30,437,689,893$ & 282.27 \\
\hline 41 & 2016Q4 & $465,647,937$ & $31,865,094,926$ & 292.54 \\
\hline 42 & 2017Q1 & $419,665,769$ & $25,471,123,330$ & 305.24 \\
\hline 43 & 2017Q2 & $464,603,675$ & $33,059,738,064$ & 309.78 \\
\hline 44 & 2017Q3 & $448,470,450$ & $36,195,914,352$ & 313.88 \\
\hline 45 & 2017Q4 & $585,787,518$ & $33,441,569,835$ & 327.41 \\
\hline 46 & 2018Q1 & $515,976,393$ & $27,202,693,072$ & 336.48 \\
\hline 47 & 2018Q2 & $590,861,707$ & $33,549,423,033$ & 357.44 \\
\hline 48 & 2018Q3 & $469,883,526$ & $33,922,918,350$ & 390.84 \\
\hline 49 & 2018Q4 & $634,605,495$ & $30,818,716,826$ & 393.88 \\
\hline 50 & 2019Q1 & $571,865,150$ & $24,663,446,184$ & 402.81 \\
\hline 51 & 2019Q2 & $487,643,924$ & $29,283,595,820$ & 413.63 \\
\hline 52 & 2019Q3 & $532,857,127$ & $31,123,761,459$ & 427.04 \\
\hline 53 & 2019Q4 & $710,177,593$ & $29,640,044,785$ & 440.50 \\
\hline
\end{tabular}

Source: Insurance Association of Turkey (TSB) and Turkish Statistical Institute (TurkStat). 


\subsection{Analyzing the Relationship between the Growth of Engineering Insurance Premiums and the Construction Sector Growth.}

\subsubsection{Stationarity Test of Variables}

Before starting an econometric time series analysis, series need to be tested for stationarity. When stationarity analysis is skipped over, spurious regression may occur, and this may lead to unrealistic analysis results (Newbold \& Granger, 1974). Stationarity analysis is administered with the use of unit root tests. Scholars generally use one of the Dickey-Fuller (DF) test, the Augmented Dickey-Fuller (ADF) test or the Philips-Perron (PP) test for the stationarity analysis (Li, Cheng, \& Shoaib, 2018). In this study, the Augmented Dickey-Fuller test, which is the most commonly used test for unit root analysis, is employed. ADF unit root test is implemented by utilizing three models. These models are in order; no trend no intercept model, the model with intercept, and the model with trend and intercept. Unit root results obtained from these three models are compared to MacKinnon critical values in $1 \%, 5 \%$, and $10 \%$ statistical significance levels, and the results of this analysis are tested against the null hypothesis and the alternative hypothesis (MacKinnon, 1996). The null hypothesis $\mathrm{H}_{0}(1)$ and the alternative hypothesis $\mathrm{H}_{1}(2)$ correspond to the following cases:

$$
\mathrm{H}_{0} \text { : if } \delta=0, \mathrm{Y}_{\mathrm{t}} \text { has a unit root, and it is non-stationary. }
$$

$\mathrm{H}_{1}$ : if $\delta<0, \mathrm{Y}_{\mathrm{t}}$ doesn't have a unit root, and it is stationary.

The $\mathrm{H}_{0}$ hypothesis shows that the series has a unit root; hence, it is not stationary, whereas the $\mathrm{H}_{1}$ alternative hypothesis shows that the series does not have a unit root; hence, it is stationary.

Obtainment of the stationarity condition with the administration of the ADF unit root tests would provide an opportunity for the analysis of the causality with the aid of the Granger causality test. For the preparation of the Granger causality test, the series to whose stationarity is ensured during the unit root test need to be analyzed for the lag length. The Granger causality test is conducted after the determination of the proper lag length. The Granger causality test is the most common method due to its convenience in the application. The Granger causality test is used to check whether there is a relationship between the series. If there is a relationship, the direction of the relationship is also determined.

The model for the Granger causality test is presented below:

$$
\begin{aligned}
& \mathrm{y}_{1 \mathrm{t}}=\alpha_{10}+\beta_{11} \mathrm{y}_{1 \mathrm{t}-1}+\beta_{12} \mathrm{y}_{2 \mathrm{t}-1}+\gamma_{11} \mathrm{y}_{1 \mathrm{t}-2}+\gamma_{12} \mathrm{y}_{2 \mathrm{t}-2}+\delta_{11} \mathrm{y}_{1 \mathrm{t}-3}+\delta_{12} \mathrm{y}_{2 \mathrm{t}-3}+\mathrm{u}_{1 \mathrm{t}} \\
& \mathrm{y}_{1 \mathrm{t}}=\alpha_{20}+\beta_{21} \mathrm{y}_{1 \mathrm{t}-1}+\beta_{22} \mathrm{y}_{2 \mathrm{t}-1}+\gamma_{21} \mathrm{y}_{1 \mathrm{t}-2}+\gamma_{22} \mathrm{y}_{2 \mathrm{t}-2}+\delta_{12} \mathrm{y}_{1 \mathrm{t}-3}+\delta_{22} \mathrm{y}_{2 \mathrm{t}-3}+\mathrm{u}_{2 \mathrm{t}}
\end{aligned}
$$

The Granger causality test is performed by testing the hypothesis, which states that the coefficients for the lagged values of the independent variable in two equations above equal to 0 as a group at a certain level of statistical significance (Küçüksille \& Karaoğlan, 2016). If the coefficients in the equation (3) are not equal to 0 as a group at a certain level of statistical significance, it shows that $\mathrm{X}$ is a Granger cause for $\mathrm{Y}$. Similar to equation (3) if coefficients in equation (4) are not equal to 0 at a particular statistical significance level, the conclusion states that $\mathrm{Y}$ is a Granger cause for $\mathrm{X}$ (Granger, 1969). In the above two equations, instead of the $\mathrm{X}$ and $\mathrm{Y}$ variables, the Granger causality between them is attempted to be reached by using the variables that are the main subject of econometric study.

For the analysis of the stationarity, Augmented Dickey-Fuller test, the most common test for unit root analysis, is utilized. MUHPRIM variable, which corresponds to the engineering insurance premiums, provided the necessary conditions at its first difference level and have shown stationarity characteristics. The variables INSGSYIH, which denotes the total size of the construction sector, and TUFE, which is Consumer Price Index (CPI),

\begin{tabular}{|c|c|c|c|}
\hline \multicolumn{4}{|c|}{$\begin{array}{l}\text { Null Hypothesis: FARK1MUHPRIM has a unit root } \\
\text { Exogenous: Constant, Linear Trend }\end{array}$} \\
\hline & & t-Statistic & Prob.* \\
\hline Augmented Dickey-Fuller test statistic & & -9.574724 & 0.0000 \\
\hline \multirow[t]{3}{*}{ Test critical values: } & $1 \%$ level & -4.156734 & \\
\hline & $5 \%$ level & -3.504330 & \\
\hline & $10 \%$ level & -3.181826 & \\
\hline
\end{tabular}
provided the necessary conditions at their second difference level and have shown stationarity characteristics.

Table 2. Stationarity test for engineering insurance premiums 
Table 3. Stationarity test for growth of construction sector

\begin{tabular}{|c|c|c|c|}
\hline \multirow{2}{*}{\multicolumn{4}{|c|}{$\begin{array}{l}\text { Null Hypothesis: FARK2INSGSYIH has a unit root } \\
\text { Exogenous: Constant, Linear Trend }\end{array}$}} \\
\hline & & & \\
\hline & & t-Statistic & Prob.* \\
\hline Augmented Dickey-Fuller test statistic & & -8.855736 & 0.0000 \\
\hline \multirow[t]{3}{*}{ Test critical values: } & $1 \%$ level & -4.165756 & \\
\hline & $5 \%$ level & -3.508508 & \\
\hline & $10 \%$ level & -3.184230 & \\
\hline
\end{tabular}

*MacKinnon (1996) one-sided p-values.

Table 4. Stationarity test for consumer price index

\begin{tabular}{|c|c|c|c|}
\hline \multicolumn{4}{|c|}{$\begin{array}{l}\text { Null Hypothesis: FARK2TUFE has a unit root } \\
\text { Exogenous: Constant, Linear Trend }\end{array}$} \\
\hline & & t-Statistic & Prob.* \\
\hline Augmented Dickey-Fuller test statistic & & -8.928532 & 0.0000 \\
\hline \multirow[t]{3}{*}{ Test critical values: } & $1 \%$ level & -4.156734 & \\
\hline & $5 \%$ level & -3.504330 & \\
\hline & $10 \%$ level & -3.181826 & \\
\hline
\end{tabular}

*MacKinnon (1996) one-sided p-values.

\subsubsection{Determination of Lag Length}

At the stationary series, the lag order needs to be determined before proceeding to the Granger causality test. The lag length is found as 5 and set accordingly as per the results of the tests conducted in EViews.

Table 5. Determination of the lag length

\begin{tabular}{|c|c|c|c|c|c|c|}
\hline \multicolumn{7}{|c|}{$\begin{array}{l}\text { VAR Lag Order Selection Criteria } \\
\text { Endogenous variables: FARK1MUHPRIM FARK2INSGSYIH FARK2TUFE } \\
\quad \text { Exogenous variables: C }\end{array}$} \\
\hline Lag & $\log L$ & LR & FPE & AIC & $\mathrm{SC}$ & HQ \\
\hline 0 & -2107.410 & NA & $1.09 \mathrm{e}+37$ & 93.79602 & 93.91646 & 93.84092 \\
\hline 1 & -2077.879 & 53.81255 & $4.39 \mathrm{e}+36$ & 92.88352 & 93.36529 & 93.06312 \\
\hline 2 & -2048.744 & 49.20522 & $1.80 \mathrm{e}+36$ & 91.98864 & 92.83175 & 92.30294 \\
\hline 3 & -2003.338 & 70.63285 & $3.63 \mathrm{e}+35$ & 90.37056 & $91.57500^{*}$ & 90.81956 \\
\hline 4 & -1986.415 & $24.06822 *$ & $2.63 e+35$ & 90.01843 & 91.58420 & 90.60213 \\
\hline 5 & -1973.751 & 16.32212 & $2.34 \mathrm{e}+35^{*}$ & $89.85560 *$ & 91.78270 & $90.57400 *$ \\
\hline 6 & -1968.916 & 5.586537 & $3.02 \mathrm{e}+35$ & 90.04073 & 92.32917 & 90.89384 \\
\hline
\end{tabular}

* indicates lag order selected by the criterion

LR: sequential modified LR test statistic (each test at 5\% level)

FPE: Final prediction error

AIC: Akaike information criterion

SC: Schwarz information criterion

HQ: Hannan-Quinn information criterion

\subsubsection{Granger Causality Analysis}

The Granger causality analysis is used for identifying the relationship between variables and the direction of the causality. Findings from EViews are presented in Table 6.

Table 6. Granger causality analysis and findings from Eviews

\begin{tabular}{cccc}
\hline $\begin{array}{l}\text { VAR Granger Causality/Block Exogeneity Wald Tests } \\
\text { Dependent variable: FARK1MUHPRIM }\end{array}$ & & \\
\hline Excluded & Chi-sq & df & Prob. \\
\hline FARK2INSGSYIH & 14.09479 & 5 & 0.0150 \\
FARK2TUFE & 24.28178 & 5 & 0.0002 \\
All & 42.72395 & 10 & 0.0000 \\
\hline
\end{tabular}




\begin{tabular}{cccc}
\hline Dependent variable: FARK2INSGSYIH & & & \\
\hline Excluded & Chi-sq & df & Prob. \\
\hline FARK1MUHPRIM & 12.55936 & 5 & 0.0279 \\
FARK2TUFE & 13.42588 & 5 & 0.0197 \\
All & 24.99507 & 10 & 0.0054 \\
\hline Dependent variable: FARK2TUFE & & & Prob. \\
\hline EARK1MUded & Chi-sq & df & 0.1209 \\
FARK2INSGSYIH & 8.716662 & 5 & 0.7081 \\
All & 2.947692 & 5 & 0.4536 \\
\hline
\end{tabular}

We can summarize and evaluate the findings from Eviews as following:

Dependent Variable: Engineering Insurance Premiums (MUHPRIM)

H0: Reject the hypothesis

H1: Accept the hypothesis $\mathrm{p}=0.0000<0.05$

INSGSYIH: $\mathrm{p}=0.0150<0.05$ The Causality is achieved. The growth of the construction sector is a cause of the increase in engineering insurance premiums. Bilateral relation exists.

TUFE: $p=0.0002<0.05$ The Causality is achieved. The increase in the consumer price index is a cause of the increase in the engineering insurance premiums. Unilateral relation exists.

Dependent Variable: Growth of the Construction Sector (INSGSYIH)

H0: Reject the hypothesis

H1: Accept the hypothesis $\mathrm{p}=0.0054<0.05$

MUHPRIM: $p=0.0279<0.05$ The Causality is achieved. The increase in engineering insurance premiums is a cause of the growth of the construction sector. Bilateral relation exists.

TUFE: $p=0.0197<0.05$ The Causality is achieved. The increase in the consumer price index is a cause of increase in the growth of the construction sector. Unilateral relation exists.

Dependent Variable: Consumer Price Index (TUFE)

H0: Accept the hypothesis $\mathrm{p}=0.4536>0.05$

H1: Reject the hypothesis

MUHPRIM: $p=0.1209>0.05$ There is no causality.

INSGSYIH: $\mathrm{p}=0.7081>0.05$ There is no causality.

The growth of the construction sector is not a cause of the increase in the consumer price index.

The increase in engineering insurance premiums is not a cause of the increase in the consumer price index.

The diagrammatic display of the relationships revealed by the study is presented in Figure 6. The usage of and growth in engineering insurances is a cause for the growth in the construction sector. In addition, the rise in consumer prices is a cause for the construction sector growth. The increase in the TUFE and the growth of the construction sector is a cause for the growth of the engineering insurances.

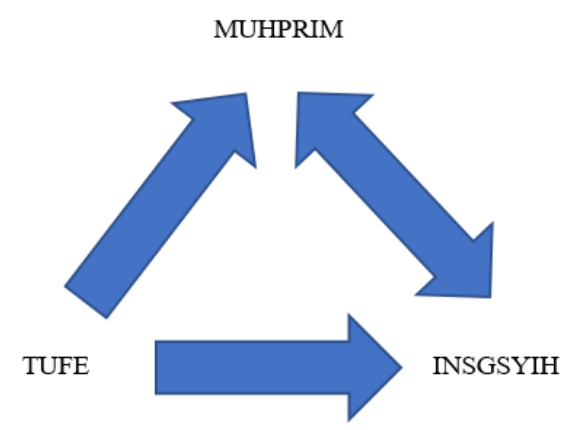

Figure 6. Relations revealed in the Granger causality test 


\subsection{Investigation of the Effect of Engineering Insurances Growth on the Growth of the Construction Sector with} Simple Linear Regression

In this study, the aim is to assess the growth of engineering insurances, which is thought as a factor of the construction sector growth and to demonstrate the relationship between them. In this vein, quarterly data for the 2006-2019 period is used. The quarterly data on engineering insurance premiums and share of the construction economic activity in Gross Domestic Product constitute our variables. The variables are obtained from TurkStat and the Insurance Association of Turkey sources and compiled. The investigation of the effect of the growth of the engineering insurances on the growth of the construction sector is targeted.

Simple linear regression is defined as the mathematical model for the linear relationship (cause and effect) between two variables.

$$
Y i=\alpha+\beta X_{i}+e_{i}
$$

Y: Dependent variable

$\mathrm{X}$ : Independent variable

$\alpha$ : Value of the dependent variable when the independent variable is zero (Intercept term)

$\beta$ : The change in the dependent variable in case of one unit increase or decrease in the independent variable.

$e$ : Error term. It is a value calculated from the sample (Turanl1 et al., 2017).

In search of a model for variables, logarithmic transformation is applied because of the interference of the high coefficient value to the rendition of the results and to obtain more relevant results. Construction of a model via simple linear regression of the logarithms of the variables is targeted. The variables are exhibited in Table 1 . The explanation of the dependent and independent variables appears below. EViews 8 Econometric Analysis Application is utilized for the study.

Dependent variable:

INSGSYIH: Quarterly sum of the share of the construction economic activity in Gross Domestic Product Independent variable:

MUHPRIM: Quarterly sum of the engineering insurance premiums

Table 7 shows the descriptive statistics for the variables.

Table 7. Descriptive statistics

\begin{tabular}{lll}
\hline & INSGSYIH & MUHPRIM \\
\hline Mean & $23,639,607,256$ & $303,027,742$ \\
Median & $23,981,986,365$ & $271,530,549$ \\
Maximum & $36,195,914,351$ & $710,177,592$ \\
Minimum & $11,033,964,806$ & $81,126,848$ \\
Std. Dev. & $6,622,326,684$ & $160,270,136$ \\
Skewness & -0.059145 & 0.638528 \\
Kurtosis & 1.898280 & 2.419476 \\
Jarque-Bera & 2.711348 & 4.345740 \\
Probability & 0.257773 & 0.113850 \\
Sum & $1,252,899,184,589$ & $16,060,470,354$ \\
Sum Sq. Dev. & $2.28047 \mathrm{E}+21$ & $1.3357 \mathrm{E}+18$ \\
Observations & 53 & 53 \\
\hline
\end{tabular}

Our data that comprise of the dependent and independent variables encompass a period between Q4 2006 and Q4 2019. The logarithms of the 53 data points on dependent and independent variables are calculated, a simple linear regression analysis is made in EViews 8 and the model is found to be meaningful. The formula for the simple linear regression is introduced below:

$$
I N S G S Y I H=\alpha+\beta 1(M U H P R I M)+e_{i}
$$

Hypotheses below are developed following the model regarding the dependent variable INSGSYIH and the independent variable MUHPRIM. $\mathrm{H}_{0}: \beta_{1}=0, \mathrm{H}_{1}: \beta_{1} \neq 0$

H0: The independent variable MUHPRIM does not affect the dependent variable INSGSYIH

H1: The independent variable MUHPRIM affects the dependent variable INSGSYIH. 
When the model results in the Table 8 are evaluated, $\mathrm{R}$-squared $\left(\mathrm{R}^{2}\right)$, which is a proxy for the explanatory power of the independent variable on the dependent variable, is found as $69 \%$. This measure signifies that the independent variable can explain 0.69 of the change in the dependent variable. The intercept term and the independent variable $(\mathrm{p}<0.01)$ is statistically significant at $1 \%$ level. The Durbin-Watson statistic, which is a control step, supposed to be in 1.5-2.5 interval. The statistic value of 1.55 is appropriate. The model is statistically significant. MUHPRIM independent variable affects INSGSYIH dependent variable.

Table 8. Investigation of simple linear regression

\begin{tabular}{|c|c|c|c|c|}
\hline \multicolumn{5}{|c|}{$\begin{array}{l}\text { Dependent Variable: LNINSGSYIH } \\
\text { Method: Least Squares }\end{array}$} \\
\hline $\begin{array}{c}\text { Variable } \\
\end{array}$ & Coefficient & Std. Error & t-Statistic & Prob. \\
\hline LNMUHPRIM & 0.456329 & 0.042707 & 10.68501 & 0.0000 \\
\hline $\mathrm{C}$ & 14.99722 & 0.828282 & 18.10642 & 0.0000 \\
\hline $\mathrm{R}$-squared & 0.691226 & Mean dependent var & & 23.84394 \\
\hline Adjusted R-squared & 0.685172 & S.D. dependent var & & 0.301499 \\
\hline S.E. of regression & 0.169170 & Akaike info criterion & & -0.678819 \\
\hline Sum squared resid & 1.459543 & Schwarz criterion & & -0.604469 \\
\hline Log likelihood & 19.98872 & Hannan-Quinn criter. & & -0.650228 \\
\hline F-statistic & 114.1694 & Durbin-Watson stat & & 1.554869 \\
\hline Prob(F-statistic) & 0.000000 & & & \\
\hline
\end{tabular}

The formula for the model in the light of findings in Table 8 is the following when the values of the coefficients are taken into account.

INSGSYIH $=14.99722+0.45632$ MUHPRIM

It is observed that the increase in engineering premiums has a positive effect on the growth of the construction sector. Growth of engineering insurance premiums has a positive effect on the GDP value of the construction.

\section{Conclusion}

The construction sector is one of the cornerstones of the economy. As construction and investments continue in a country, it is thought that development will be continuous as well. The engineering insurances are crucial risk transfer instruments, which play a vital role in the risk management of construction projects. The compensation of the considerable damages in the construction projects in a hasty manner secures the contractors' and investors' ability to continue the business and engage in new projects, by indemnifying their monetary loss. The capacity for rapid recovery and progression is an issue of importance in terms of economic development. The construction projects bear numerous risks and require meticulous management. For this reason, it is thought that proper management of the associated risks in the construction sector by means of the risk transfer to insurance sector via engineering insurances will contribute the sustainable growth of the construction sector. The effect of engineering insurances on the construction sector growth is investigated with empirical data in this study and positive conclusions are achieved. The increase of using engineering insurances is a cause of the construction sector growth. Causality is proven in the Granger causality test, which are conducted for the measurement of causality. The construction sector growth is also a cause of the increase in engineering insurance premiums. A bilateral relation is observed between the construction sector growth and the growth of engineering insurances. Additionally, simple linear regression is applied for the identification of the impact of the growth of engineering insurances on the construction sector growth. For this purpose, the econometric analysis software is run, and a statistically meaningful result is obtained. According to the result, the independent variable MUHPRIM shows an effect on the dependent variable INSGSYIH. The positive increase in engineering insurance premiums increases the gross domestic product of construction. When engineering insurance premiums increase, the growth of the construction sector also escalates. The effect of engineering insurances as crucial risk transfer tools is thought to be positive on construction risk management and the construction sector growth. The results of the study, which is conducted by utilizing empirical data, are considered as justifiers of this deduction.

\section{References}

Bunni, N.G. (2003). Risk and insurance in construction. London and New York: Spon Press. https://doi.org/10.4324/9780203476543

Catalan, M., Impavido, G., \& Musalem, A. (2000). Contractual savings or stock markets development: Which leads? (World bank policy research paper 2421). Washington: The World Bank. 
https://doi.org/10.1596/1813-9450-2421

Granger, C. W. (1969). Investigating Causal Relations by Econometric Models and Cross-spectral Methods. Econometrica, 37(3), 424-438. https://doi.org/10.2307/1912791

Gündeş, S. (2011). Exploring the dynamics of the Turkish construction industry using input-output analysis. Construction Management and Economics, 29(1), 59-68. https://doi.org/10.1080/01446193.2010.529925

Gündeş, S. (2017). İnşaat Sektöründeki Yüklenicilerin Finansman Tercihlerinin ve Sorunlarının Belirlenmesi. Istanbul: MSGSUBAP 2017/1.

Haiss, P., \& Sumegi, K. (2008). The relationship between Insurance and economic growth in Europe: A Theoretical and Empirical Analysis. Empirica, 35(4). https://doi.org/10.1007/s10663-008-9075-2

Insaat nedir? In Insaat Santiye. Retrieved March 15, 2020, from https://www.insaatsantiye.com/insaat-nedir/

Insurance Association of Turkey. Retrieved from https://www.tsb.org.tr

Karluk, S. R. (2002). Türkiye Ekonomisi, Tarihsel Gelişim, Yapısal ve Sosyal Değişsim. İstanbul: Beta Basım.

Koç, E., Kaya K., \& Şenel, M. C. (2017). Türkiye'de İnşaat Sanayi Sektörünün Gelişimi-Temel İnşaat Sanayi Göstergeleri. Nevşehir Bilim ve Teknoloji Dergisi, Cilt 6(2), 643-660. https://doi.org/10.17100/nevbiltek.305577

Küçüksille, E., \& Karaoğlan S. (2016). Kırılgan Beşli Ülkelerin Amerikan Doları Bazında Parite Getirileri Arasındaki İlişkilerin Analizi. Dumlupınar Üniversitesi Sosyal Bilimler Dergisi, 50, 46-61. Retrieved from https://dergipark.org.tr/tr/pub/dpusbe/issue/31354/345365

MacKinnon, J. G. (1996). Numerical distribution functions for unit root and cointegration tests. Journal of Applied Econometrics, 11(6), 601-618. https://doi.org/10.1002/(SICI)1099-1255(199611)11:6<601::AID-JAE417>3.0.CO;2-T

Man Li, R. Y., Cheng, K. Y., \& Shoaib, M. (2018). Walled Buildings, Sustainability, and Housing Prices: An Artificial Neural Network Approach. Sustainability, 10(4), 1298. https://doi.org/10.3390/su10041298

Manson, R. (2000). Allianz Global Risk Report 2000 (Report No 4/2000). Munich: Allianz.

Newbold, P., \& W. Granger, C. W. (1974). Experience with Forecasting Univariate Time Series and the Combination of Forecasts. Journal of the Royal Statistical Society, 197(2), 135. https://doi.org/10.2307/2344546

Özbolat, M. (2009). Temel Sigortacılık. Ankara: Seçkin Yayınları.

Public Procurement Law. (2002). Retrieved from https://www.mevzuat.gov.tr/MevzuatMetin/1.5.4734.pdf

Rule, D. (2001). Risk transfer between banks, insurance companies and capital markets: An overview (Issue No 11). London: Bank of England.

Swiss Re. (2018). Swiss Re Sigma- Constructing the future: Recent developments in engineering insurance (No 2). Zurich: Swiss Re Institute.

Turanl1, M., Güriş, S., Cengiz, D., Özden, Ü. H., Başar, Ö. D., \& Kalkan, S. B. (2017). İstatistik El Kitabl. İstanbul: DER Yayınları.

Turkish Contractors Association. (2020). Yurtdlşı Müteahhitlik Hizmetleri Raporu. Ankara: Türkiye Müteahhitler Birliği.

Turkish Language Association. (2020). Retrieved from https://sozluk.gov.tr/

Turkish Statistical Institute. (2020). Retrieved from http://www.tuik.gov.tr/

\section{Copyrights}

Copyright for this article is retained by the author(s), with first publication rights granted to the journal.

This is an open-access article distributed under the terms and conditions of the Creative Commons Attribution license (http://creativecommons.org/licenses/by/4.0/). 